Economic and Environmental Geology

Review

\title{
Sustainable Development Plan for Domestic Forest Aggregate Development according to Transport Distance
}

\author{
Dong-Kil Lee ${ }^{1, *}$ and Jin-Young Lee ${ }^{2}$ \\ ${ }^{1}$ Mineral Resource Research Division, Korea Institute of Geoscience and Mineral Resources, Daejeon 34132, Korea \\ ${ }^{2}$ Geologic Resarch Center, Korea Institute of Geoscience and Mineral Resources, Daejeon 34132, Korea \\ *Corresponding author : ldk@kigam.re.kr

\section{ARTICLE INFORMATION} \\ Manuscript received 11 August 2021 \\ Received in revised form 19 August 2021 \\ Manuscript accepted 20 August 2021 \\ Available online 29 October 2021 \\ DOI : http://dx.doi.org/10.9719/EEG.2021.54.5.495

\begin{abstract}
Research Highlights
- When the production sites of forest aggregates are located at a long distance from large cities, we proposed a plan to reduce transportation costs for stable supply and demand of aggregates.

- When the production sites of forest aggregates are located in a short distance from a large city, a exploitation method of aggregate from underground is proposed for stable supply and demand of aggregates.

- Problems that act as obstacles to revitalize forest aggregate development were presented and improvement methods were suggested.
\end{abstract}

\begin{abstract}
Aggregate is a major natural resource used in SOC construction, such as housing, roads, ports, etc., and is a fundamental material for national construction. Although aggregates account for only about $4 \%$ of the construction cost, aggregates occupy about $80 \%$ of the construction volume and are essential factors that determine the quantity and quality of buildings. For river, underwater, riverbed, sea, and land aggregates, it is difficult to rapidly increase the production of aggregates when there is difficulty in supply and demand due to environmental problems and limited resources during production, whereas forest aggregates are relatively easy to increase production. Forest aggregates are considered promising as alternative aggregate resources in the future when reducing other aggregates due to their abundance of natural resources, and are an effective aggregate source that can flexibly respond to aggregate demand in accordance with well-organized plans and policies. This study proposed the plan for activating the development of forest aggregates in the case of long and short transport distances, which is a factor that has a great influence on the development, and measures for the current difficulties in forest aggregate development.
\end{abstract}

Keywords : forest aggregate, transportation distance, sustainability, countermeasures, underground

Citation: Lee, D.-K., Lee, J.-Y. (2021) Sustainable Development Plan for Domestic Forest Aggregate Development according to Transport Distance. Korea Economic and Environmental Geology, v.54, p.495-503, doi:10.9719/EEG2021.54.5.495.

This is an Open Access article distributed under the terms of the Creative Commons Attribution Non-Commercial License (http://creativecommons.org/ licenses/by-nc/3.0) which permits unrestricted non-commercial use, distribution, and reproduction in any medium, provided original work is properly cited. pISSN 1225-7281; eISSN 2288-7962/@2021 The KSEEG. Printed by Hanrimwon Publishing Company. All rights reserved. 


\section{해설}

\section{운반거리에 따른 국내 산림골재 개발의 지속 개발 방안}

이동길 ${ }^{1, *} \cdot$ 이진영 ${ }^{2}$

1한국지질자원연구원 자원탐사개발연구센터

2한국지질자원연구원 지질연구센터

*책임저자 : ldk@kigam.re.kr

\section{요 약}

골재는 주택 및 도로.항만 등과 같은 SOC건설에 사용되는 주요한 천연자원이며 국가건설의 기본이 되는 기초자재이다. 골재가 공사원가에서 차지하는 비중은 약 $4 \%$ 에 불과하나, 골재는 건설공사 용적의 약 $80 \%$ 를 점유함으로서 건설공사의 양과 질을 좌 우하는 필수요소이다. 하천, 수중, 하상, 바다, 육상 골재는 생산시 환경 문제와 제한된 부존량으로 인해 골재수급에 어려움이 발생할 경우 골재의 생산량을 급격하게 증가시키기 어려운 반면에 산림골재는 증산이 비교적 용이하다. 산림골재는 부존량이 풍부해 향후 다른 골재 감축시 대체 골재자원으로 유망하게 평가받고 있으며, 잘 짜여진 계획과 정책에 따라 골재수요에 유연 하게 대응할 수 있는 효과적인 골재재원이다. 본 연구에서는 산림골재 개발에 큰 영향을 미치는 운반거리를 중심으로, 운반거 리가 긴 경우와 짧은 경우에 대해서 산림골재 활성화 방안과 더불어 현재 산림골재 개발의 난제에 대한 대책을 제시하였다.

주요어 : 산림골재, 운송거리, 지속가능성, 대책, 지하

\section{1. 서 론}

골재는 주택 및 도로·항만 등과 같은 SOC건설에 사용 되는 주요한 천연자원이며 국가건설의 기본이 되는 기초 자재로서, 우리나라에서 연간 2 억 5 천만 $\mathrm{m}^{3}$ 내외의 막대 한 양의 골재가 주택건설, 토목, 도로 등에 사용되고 있 다 (Hong and Lee, 2020). 이러한 골재는 자연산물로서 현실적으로 대체재의 개발이 쉽지 않으며, 그 양의 방대 함으로 인해 수입으로 충당할 수 없다는 특성을 가지고 있다 (Won, 2004). 우리나라의 골재산업의 규모는 연간 약 2 조원, 골재가 공사원가에서 차지하는 비중은 약 $4 \%$ 에 불과하나, 골재는 건설공사 용적의 약 $80 \%$ 를 점유함 으로서 건설공사의 양과 질을 좌우하는 필수요소이다 (KAA, 2021).

이처럼 골재는 국가경제 성장과 국민복지 향상에 기반 이 되는 건설산업의 기초재료로서 안정적인 공급이 중요 하기 때문에 정부는 골재의 수급현황을 파악하여 골재의 수급이 원활하도록 조정하기 위해 1993년에 골재채취법 을 제정하였다. 이를 기반으로 국토교통부에서 매년 5년 마다 골재수급기본계획을 수립하고 있으며, 시도별 골재 채취현황에 대한 통계를 골재자원정보관리시스템 (https:// www.agris.go.kr)을 통해 공개하고 있다 (MLIT, 2018).

Table 1은 2014년부터 2018년까지 골재의 종류별 생산 실적을 나타낸다. 골재는 입자의 크기, 제조, 비중, 용도
에 따라 다양하게 분류할 수 있지만, 골재채취법 시행령 제 2 조 1 항에서는 채취장소에 따라 하천골재, 수중골재, 하상골재, 바다골재, 산림골재, 육상골재의 6 개로 분류하 고 있다.

표에서와 같이 하천골재, 바다골재, 육상골재의 생산량 은 비교적 낮은 반면에 산림골재와 선별파쇄골재가 높은 비율을 차지하는 것을 확인할 수 있다. 여기에서 신고된 선별파쇄 골재는 직접 골재 채취허가를 취득하여 골재를 생산한 것이 아니라 단지 골재 생산설비만을 갖추고 원 석의 공급은 다른 곳에서 받아 선별파쇄, 세척 등의 과 정을 통해 생산되는 골재량을 말한다 (Hong et al., 2015). 2018년 기준으로 수요대비 허가 및 신고된 공급실적은 전체의 $74.5 \%$ 이고 나머지 $25.5 \%$ 는 지자체의 골재채취 허가 및 신고 통계에 포함되지 않는 순환골재와 부수적 인 골재 등을 통해 공급된 양이다.

제 6차 골재수급 기본계획 (MLIT, 2018)에 제시된 골 재수급 전망을 살펴보면, 하천골재와 바다골재는 환경문 제에 대한 논란으로 인해 비중이 점차 축소될 것이며, 육 상골재는 제한된 부존량으로 현 수준을 유지할 것으로 전망하고 있다. 반면에 선별파쇄골재는 국내 건설경기 활 성화에 따라 높은 공급비중을 유지해 왔으며, 자원 재활 용 차원에서도 긍정적으로 평가받고 있다.

이중에서 하천, 수중, 하상, 바다, 육상 골재는 생산시 환경 문제와 제한된 부존량으로 인해 골재수급에 어려움 
Table 1. Domestic production by type of aggregate from 2014 to 2018 (MLIT, 2018)

(Unit : $\left.1000 \mathrm{~m}^{3}, \%\right)$

\begin{tabular}{|c|c|c|c|c|c|c|c|c|}
\hline \multicolumn{3}{|c|}{ Year } & 2014 & 2015 & 2016 & 2017 & 2018 & Annual Avg. \\
\hline \multicolumn{3}{|c|}{ Demand(estimate) } & 202,426 & 215,767 & 238,033 & 256,100 & 251,490 & 232,763 \\
\hline \multirow{2}{*}{\multicolumn{3}{|c|}{$\begin{array}{l}\text { Permitted and declared supply } \\
\text { (Relative to demand) }\end{array}$}} & 145,092 & 157,935 & 197,898 & 182,271 & 187,278 & 174,095 \\
\hline & & & $71.7 \%$ & $73.2 \%$ & $83.1 \%$ & $71.2 \%$ & $74.5 \%$ & $74.8 \%$ \\
\hline \multirow{12}{*}{ Permission } & \multirow{2}{*}{ Sum } & Vol. & 84,701 & 92,004 & 114,230 & 98,233 & 100,105 & 97,855 \\
\hline & & Percent & $41.8 \%$ & $42.6 \%$ & $48.0 \%$ & $38.4 \%$ & $39.8 \%$ & $42.0 \%$ \\
\hline & \multirow{2}{*}{ River } & Vol. & 3,851 & 1,315 & 2,952 & 2,708 & 2,660 & 2,697 \\
\hline & & Percent & $1.9 \%$ & $0.6 \%$ & $1.2 \%$ & $1.1 \%$ & $1.1 \%$ & $1.2 \%$ \\
\hline & \multirow{2}{*}{ Sea(coast) } & Vol. & 12,972 & 13,761 & 12,772 & 7,263 & 0 & 9,354 \\
\hline & & Percent & $6.4 \%$ & $6.4 \%$ & $5.4 \%$ & $2.8 \%$ & $0.0 \%$ & $4.0 \%$ \\
\hline & \multirow{2}{*}{ Sea(EEZ) } & Vol. & 11,930 & 13,717 & 16,092 & 11,678 & 8,260 & 12,335 \\
\hline & & Percent & $5.9 \%$ & $6.4 \%$ & $6.8 \%$ & $4.6 \%$ & $3.3 \%$ & $5.3 \%$ \\
\hline & \multirow{2}{*}{ Forest } & Vol. & 51,955 & 58,774 & 78,143 & 60,538 & 73,425 & 64,567 \\
\hline & & Percent & $25.7 \%$ & $27.2 \%$ & $32.8 \%$ & $23.6 \%$ & $29.2 \%$ & $27.7 \%$ \\
\hline & \multirow{2}{*}{ Land } & Vol. & 3,993 & 4,437 & 4,271 & 16,046 & 15,760 & 8,901 \\
\hline & & Percent & $2.0 \%$ & $2.1 \%$ & $1.8 \%$ & $6.3 \%$ & $6.3 \%$ & $3.8 \%$ \\
\hline \multirow{2}{*}{ Declaration } & \multirow{2}{*}{$\begin{array}{l}\text { Screening } \\
\text { crushed }\end{array}$} & Vol. & 60,391 & 65,931 & 83,668 & 84,038 & 87,173 & 76,240 \\
\hline & & Percent & $29.8 \%$ & $30.6 \%$ & $35.1 \%$ & $32.8 \%$ & $34.7 \%$ & $32.8 \%$ \\
\hline \multirow{2}{*}{\multicolumn{2}{|c|}{$\begin{array}{c}\text { Other supply } \\
\text { (Relative to demand) }\end{array}$}} & Vol. & 57,334 & 57,832 & 40,135 & 73,829 & 64,212 & 58,668 \\
\hline & & Percent & $28.3 \%$ & $26.8 \%$ & $16.9 \%$ & $28.8 \%$ & $25.5 \%$ & $25.2 \%$ \\
\hline
\end{tabular}

이 발생할 경우 골재의 생산량을 급격하게 증가시키기 어려운 반면에 산림골재는 증산이 비교적 용이하다는 장 점이 있다. 산림골재는 국내 굵은 골재 (자갈) 생산량의 $46.9 \%$ 으로 가장 높은 비중을 차지하고 있으며, 지금까지 공급비중의 증가를 통해 골재수급 안정에 기여하고 있다. 또한 산림골재는 부존량이 풍부해 향후 다른 골재 감축 시 대체 골재자원으로 유망하게 평가받고 있으며, 잘 짜 여진 계획과 정책에 따라 골재수요에 유연하게 대응할 수 있는 효과적인 골재재원이다.

골재는 중량과 부피가 큰 반면에 상차도 기준으로 판 매가격이 일정하기 때문에 생산지에서 소비지까지의 운 반거리가 골재 구매비용에 큰 영향을 미친다. 일반적으 로 산림골재 생산지는 대도심에서 원거리에 위치하고 있 기 때문에 운반거리가 산림골재 생산여부를 판가름하는 핵심적인 요소이다. 또한 대도심 인근에 위치한 산림골 재 생산지에서는 지속적인 골재생산으로 인해 생산가능 한 골재량은 점차 감소하고 있다. 따라서 산림골재 개발 을 활성화하기 위해서는 운반거리에 따른 비용문제의 해 결과 더불어 생산가능한 골재의 확보가 중요하다. 본 연 구에서는 산림골재 개발에 가장 영향을 미치는 운반거리 를 중심으로 골재수급 안정과 더불어 보다 효과적인 산 림골재의 생산과 이용을 위한 골재생산 방안과 필요한 정책을 제시하였다.

\section{2. 물류노선 개선을 통한 원거리 산림골재 생산 방안}

일반적으로 골재의 수요지는 인구가 집중되고 사회기 반시설 구축이 활발한 대도시에 집중된다. 대도시의 대 규모 골재소비로 인해 대도시 근거리에 위치한 골재생산 지는 지가상승과 더불어 지속적인 골재생산으로 인해 조 기에 채취가 종료됨에 따라 골재 생산지는 대도시에서 점차 멀어지게 된다. 골재는 중량과 부피가 커서 장거리 운송에 많은 비용이 소요되므로 운반거리가 골재생산 및 판매에 가장 큰 영향을 미친다. 일반적으로 골재의 운송 최대거리는 약 $40 \mathrm{~km}$ 내외로 알려져 있다 (Hong and Lee, 2020).

만약 골재 운송비용을 획기적으로 낮출 수 있다면 골 재생산지역은 대도시에서 보다 원거리에 위치하더라도 경제성은 확보될 수 있으며, 대도시 골재수요에 부응하 기 위한 원거리 골재생산이 가능하게 된다. 이는 골재생 산의 대형화와 더불어 저렴한 운송방식을 선정함으로서 가능하다.

Fig. 1은 광산에서 생산된 광석을 운반하는 방식으로 철도, 트럭, 컨베이어의 3가지 수단 (Fig. 1 (a))에 대해 한 비용을 평가한 결과 (Fig. 1 (b))를 도시한 것이다. 골 재의 운반여건은 그림에서 제시한 연구조건과 상이하여 


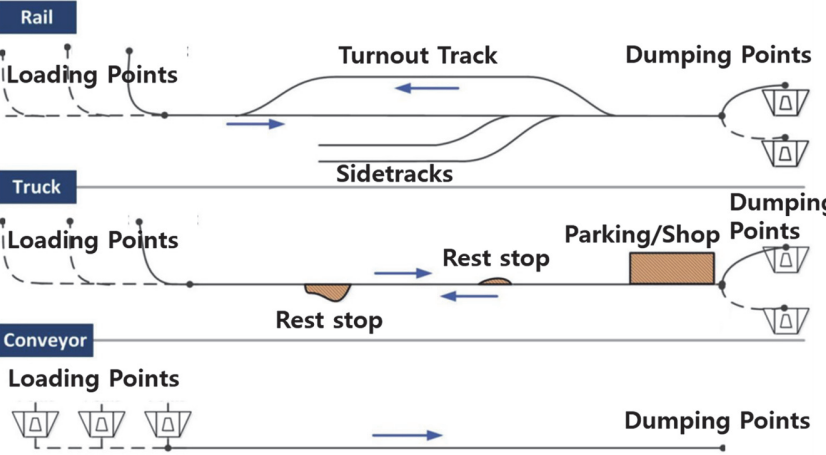

(a) Simplified haulage systems with three mining sections

\begin{tabular}{|c|c|c|c|c|c|c|}
\hline Haulage System & $\begin{array}{c}\text { Capex } \\
{[\$]}\end{array}$ & $\begin{array}{c}\text { Reinvestment } \\
{[\$]}\end{array}$ & $\begin{array}{c}\text { Opex } \\
{[\$ / \text { tROM] }}\end{array}$ & $\begin{array}{c}\text { Total Cost } \\
{[\$ / \text { tROM] }}\end{array}$ & $\begin{array}{c}\text { Equipment } \\
{[\#]}\end{array}$ & $\begin{array}{c}\text { Equipment } \\
\text { Peak [\#] }\end{array}$ \\
\hline & $100 \%$ & $100 \%$ & $100 \%$ & $100 \%$ & 5 & 7 \\
\hline & $88 \%$ & $51.4 \%$ & $166 \%$ & $145 \%$ & 17 & 22 \\
\hline
\end{tabular}

(b) key performance indicators(KPI)

Fig. 1. Cost evaluation results according to transport method in mines(Dammers et al., 2019).

절대평가는 불가하지만 운반방식에 따른 상대적인 차이 는 확인할 수 있다. Fig. 1 (b)에서와 같이 3가지 방식 중 에서 트럭운반의 비용이 가장 높다. 반면에 철도와 컨베 이어 순으로 비용이 낮아짐을 확인할 수 있다.

국내에서 골재 생산지에서 소비지까지의 골재운반은 대부분 트럭운반에 의존하고 있는 실정이지만, 장기적으
로 지속적인 골재의 수요가 존재할 경우 철도, 컨베이어 등의 운반비용이 낮은 대체 운반수단을 채택하고 가용할 수 있는 운반루트를 최적화한다면 골재 생산지가 보다 먼 거리에 위치하더라도 수익성 확보가 가능하다.

그러나 본 방안은 생산지와 소비지에 운송 인프라와 더 불어 넓은 면적의 토지확보와 적재, 하차, 저장 시설의

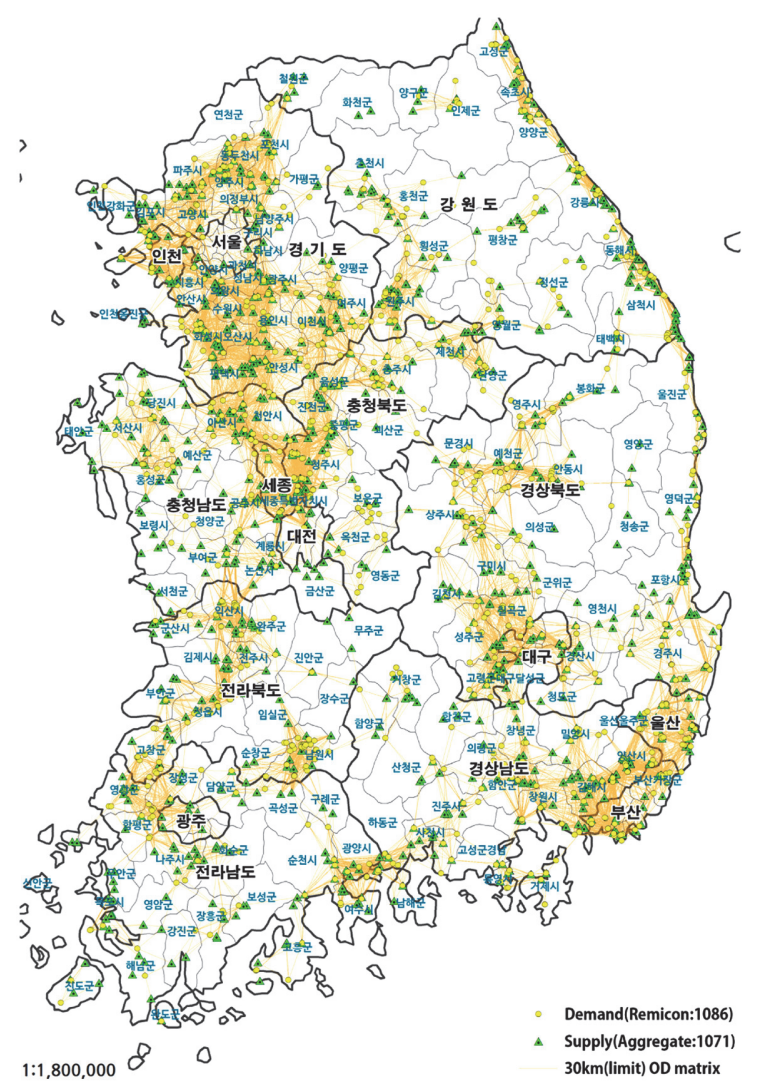

(a) Aggregate Supply Network in $30 \mathrm{~km}$ ODmatrix (KIGAM, 2020)

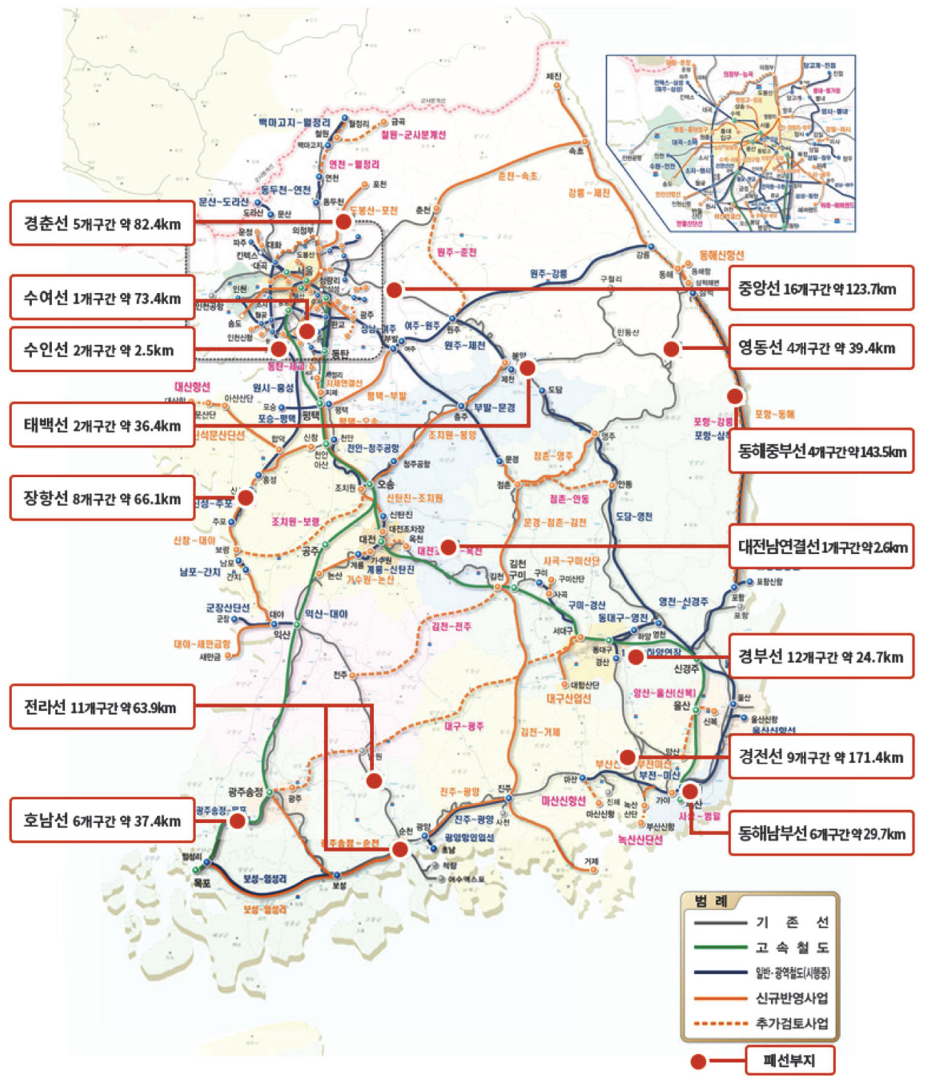

(b) Sections and locations for railway idle site (KNR, 2021)

Fig. 2. Maps of domestic aggregate supply network and idle railway site. 
구축이 요구된다는 어려움이 있다 (Fig. 2 (a)). 그러나 기 존 폐석산을 중간 저장시설로 이용하거나 활용율이 낮은 철도노선이나 미활용 중인 철도 부지를 활용하여 이러한 시설을 갖출 수 있다면 가능성은 열려있다. 철도의 경우 철도의 복선화 및 선로 개량 직선화 사업에 따른 철도유 휴부지가 발생하고 있으며 (Fig. 2 (b)), 대부분의 유휴부 지는 폭이 좁고 길이가 매우 긴 형태로 전국적으로 산재 하고 있다. 2020년 3월 기준으로 전체 철도 유휴부지 면 적은 2,566 만 $\mathrm{m}^{2}$ 이며, 폐선부지가 대부분을 차지하고 있 다 (KNR, $2020 \& 2021)$.

이처럼 민원발생 소지가 적고 생산여건이 비교적 양호 한 원거리 골재채취지역에서 생산된 골재를 저렴한 이동 수단을 이용해 도시인근의 골재 저장시설까지 최적화된 경로로 운송하고 이를 각 중간 판매상이나 수요처에 공 급할 수 있다면 골재수급의 어려움을 극복하는 효과적인 방안이 될 수 있다. 이와 같은 방안은 정부에서 추진하 고 있는 골재채취단지와 연계한다면 안정적 골재수급에 시너지 효과가 발생할 것으로 판단된다.

\section{3. 지하 골재개발을 통한 도심 근거리 산림골재 생산 방안}

대도심에서 골재소비가 지속됨에 따라 대도심 인근에 위치한 골재 생산지의 가채량은 점차 감소하게 되고 채 취가 완료되면 골재생산지는 원거리로 이동할 수밖에 없 다. 이러한 경우 골재 운반비의 증가로 인해 골재가격 상 승과 더불어 골재수급에 문제가 야기될 수 있다. 또한 대 도심 주변에 위치한 산지골재 생산지는 인근에 민가가 위치하고 있어 골재생산 중에 발생하는 먼지, 소음, 진동

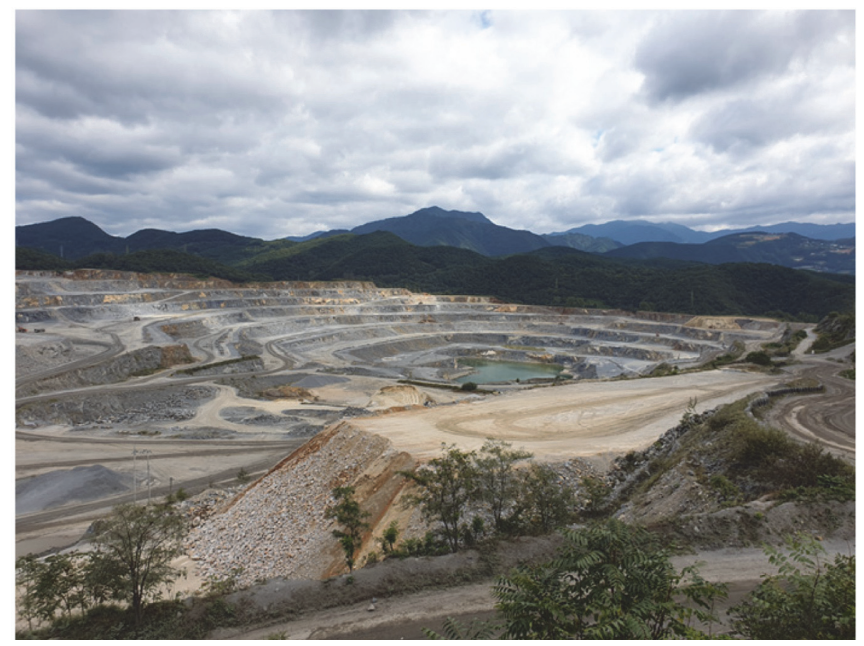

(a) Surface mine
으로 인한 인근 주민들과 마찰을 빚고 있으며, 지자체에 서 인허가를 꺼려하고 있는 실정이다.

이러한 문제를 해결할 수 있는 방법으로 지하에서 골 재를 채취하는 방법을 고려할 수 있다. 지하에서 골재를 채취할 경우 여러 가지 잇점이 있다. 먼저 중량과 부피 가 큰 반면 가격이 낮아 운반거리가 비용에 가장 영향을 많이 미치는 골재를 대도시 인근지역에서 채취할 수 있 어 운반거리가 단축될 수 있다. 그리고 지하 골재채취지 역 상부의 지표면은 다양한 용도로 경제적 활용이 가능 하며, 일반적으로 지하는 암반으로 구성되어 있으므로 골 재 자원량이 풍부해 골재의 안정적 공급을 가능케 한다. 골재를 채취한 후 남아있는 지하공간은 지하저장, 창고, 비즈니스 용도로 사용할 수 있는 등의 다양한 이점이 있 다 (Brown et al, 2010). 또한 지하에서 골재를 채취할 경 우 노천 골재채취에서에서 나타나는 골재 채취지역의 노 출은 없으며, 소음, 먼지 등 민원의 원인이 저감되고 도 심 인근에 골재채취가 가능하므로 수요에 대응이 용이한 장점이 있다.

광물을 채광하는 광산에서 지하 광산개발은 특별한 경 우가 아니다. 일반적으로 광체가 지표 인근에 위치할 때 에 광석을 채광하는 방법은 산림골재 생산방법과 동일하 게 벤치발파를 수행한다 (Fig. 3). 그러나 광체가 지하 깊 이 존재할 경우에 광산에서는 광체까지 갱도를 뚫고 지 하에 부존하는 광석을 운반이 가능한 크기로 파쇄하여 지표로 운반한다. 최근에는 지하광산내 대규모 지하공간 을 개설하고 파쇄설비를 구축해 지하에서 파·분쇄도 함 께 수행 (Fig. 3 (b))함으로서, 발파, 운반, 파·분쇄로 인 해 발생하는 먼지, 소음, 진동이 주변에 미치는 환경적 영향을 최소화해 광산개발을 수행하고 있다. 이와 동일

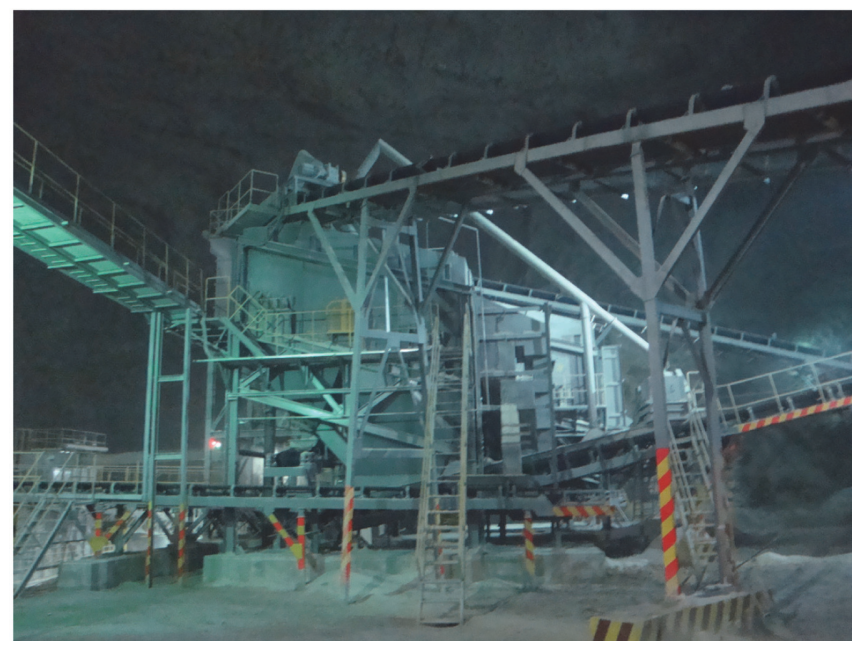

(b) Crushing facilities in underground mine

Fig. 3. View of surface mine and underground mine. 
한 방식을 골재채취에 적용한다면 노천 골재채취로 인해 발생하는 문제를 해결하는데 많은 도움이 될 것으로 판 단된다. 또한 지하 골재채취에는 지표에서보다 골재채취 방법, 장비의 선정, 지하공동의 안정성, 공기의 흐름, 지 하수의 배수 등의 고려해야할 사항이 많으나 이러한 기 술적 문제는 지하 광산개발 기술을 적용하면 해결될 수 있다.

경제적 측면에서 지하에서 골재를 채취하는 비용은 일 반적으로 지표에서 골재를 채취 비용보다 높다. 지하 골 재채취의 잇점에도 불구하고 경제적 타당성이 확보되어 야 지하 골재생산이 가능하다. 영국, 그리스, 이스라엘, 홍콩 등의 다양한 국가에서 지하 골재채취에 관한 경제 적 및 기술적 검토가 수행되어 왔다(Chan, 2019; Brown et al., 2010; Eidelman et al., 2007; Benardos et al., 2001; Stocks, 1979).

일례로 Benardos et al.(2001)은 아테네의 환경규제로 인해 노천 골재채취가 어려워짐에 따라 대안으로 지하 골재개발의 가능여부를 평가하기 위해 경제성 평가를 수 행하였다. 대상지역은 Attica의 동부에 위치한 Koropi 지 역이며, 지하에서는 골재를 생산하고 지상의 토지는 임 대하는 조건이다. 경제성 평가결과, 할인율 $6 \%$ 에 대해서 950 만 US\$의 총 현재가치와 $12.07 \%$ 의 내부수익율이 도 출됨에 따라 지하 골재생산이 경제적임을 확인시켜 주었 다. 각 연구마다 골재의 가격과 비용산정의 근거가 차이 가 있어 연구결과를 국내에 직접 적용하기에는 무리가 있으므로, 지하 골재개발을 위해서는 국내 여건을 고려 한 기술적 및 경제적 검토가 선행되어야 할 것이다.

이러한 지하 골재채취의 비용의 문제는 2 가지 방법을 융합하여 일정 부분 해소할 수 있다. 첫 번째 방법은 지 하 골재 채취공정을 효율화하여 소요되는 비용을 낮추고, 생산할 수 있는 골재의 양은 증가시키는 기술을 도입하
는 것이다. 이러한 방법은 최적 광산설계기술을 도입함 으로서 가능하다. Fig. 4는 지하광산에서 기존의 개발방 식과 최적화된 새로운 설계방식을 적용했을 때 채광비용 과 총 현재가치를 비교한 것이다 (KIGAM, 2019). 그림 에서 제시한 지하광산은 석회석을 채광하는 광산으로서, 생산조건뿐만 아니라 석회석 광체와 주변암의 물성은 국 내에서 생산하는 일반적인 산림골재와 유사하다. 그림에 서와 같이 최적화된 설계안을 적용할 경우 동일한 광체 부존량에 대해 채광된 광석의 양은 2.26 배가 증가하였다. 또한, 그림에서와 같이 할인율 $10 \%$ 일 때 생산비용은 $26.5 \%$ 까지 감소하여 총 현재가치는 기존대비 2.04 배가 증가하였다.

이처럼 지하에서 골재를 채취하기 위해서는 개발여건 에 맞는 적절한 채취방법과 더불어 최적화된 계획적 설 계를 통해 비용을 절감시킬 수 있을 뿐만 아니라 생산할 수 있는 골재의 양도 증가시킬 수 있는 장점이 있다. 또 한 생산단계에서 발생할 수 있는 다양한 문제점을 사전 에 파악해 대처할 수 있기 때문에 사후에 문제해결에 소 요되는 상당한 비용을 절감시킬 수 있다.

두 번째 방법은 지하에서 골재를 채취하기 전에 골재 채취로 인해 발생하는 지하 공간의 활용계획을 사전에 결정하고 추후 활용함으로서, 골재채취 행위를 지하공간 의 건설과정으로 관점을 전환해 부족한 도심의 공간을 확장하는 기회로 활용하는 것이다.

지하공간은 암반의 열전도율이 낮고 연간 일정한 온도 가 유지되며 주변환경에 영향을 주지 않으면서도 부지를 활용할 수 있는 장점이 있다. 또한 진동, 소리나 지상재 해의 영향을 거의 받지 않으며, 불연성이 강해 안전성 면 에서 우수하다. 핀란드, 노르웨이, 스웨덴, 캐나다, 미국, 프랑스 등의 해외 선진국에서는 이러한 지하공간의 장점

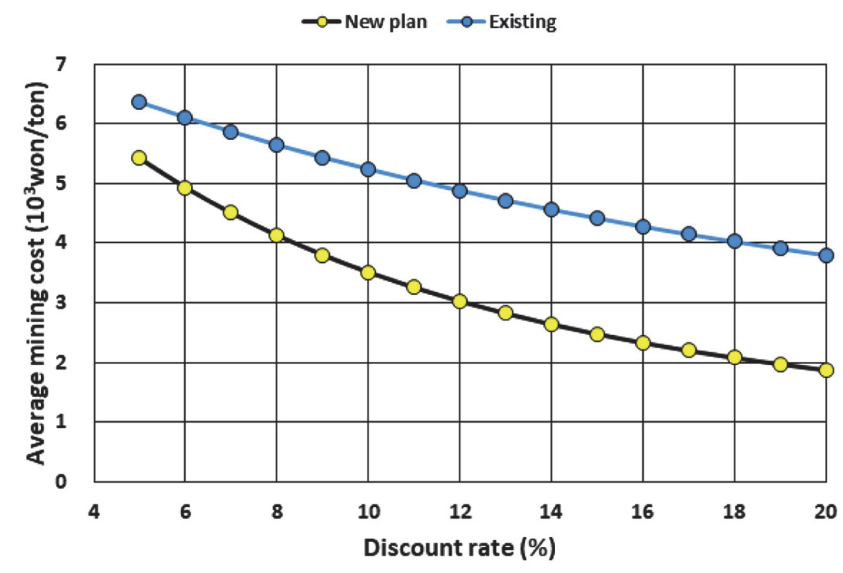

(a) Mining cost

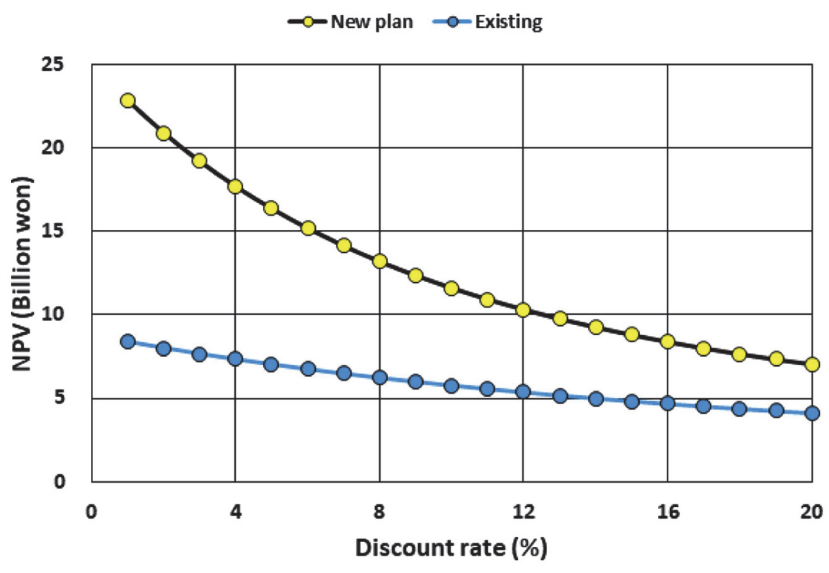

(b) Net present value

Fig. 4. Economical comparison of existing plan and new plan in OO mine(KIGAM, 2019). 


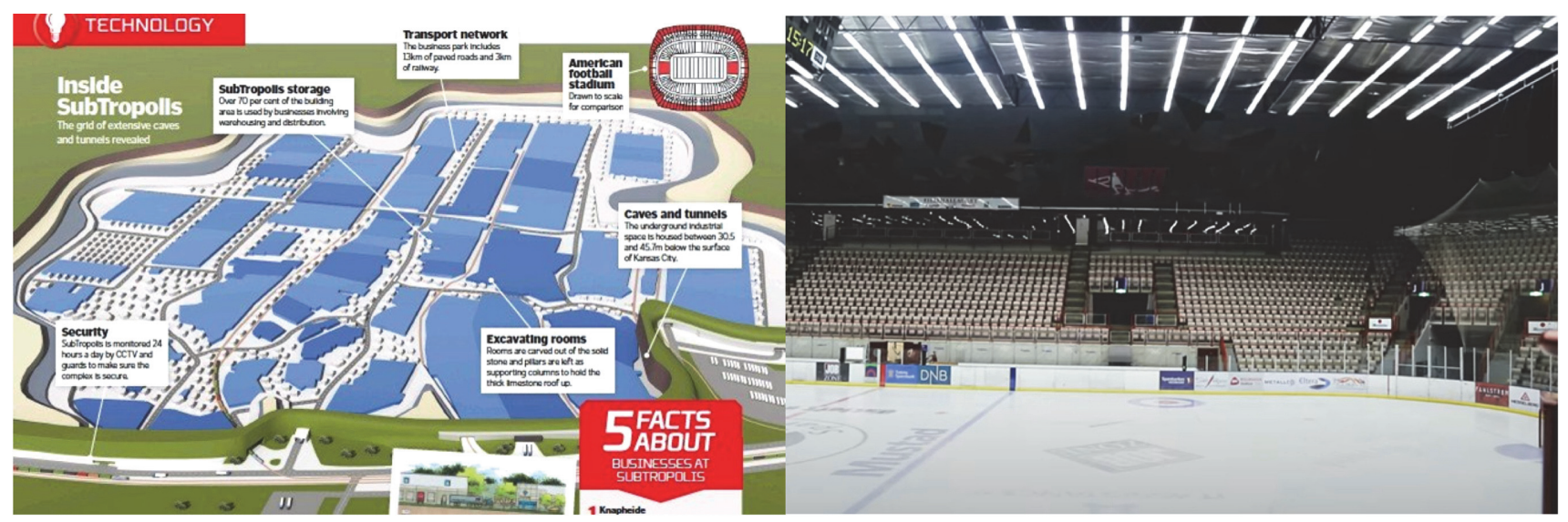

(a) Underground business complex in USA

(b) Gjøvik Olympic Cavern Hall in Norway

Fig. 5. Cases of using underground space abroad.

을 살려 광산개발 등으로 발생한 지하공간을 경기장, 저 장시설, 상-하수처리시설, 도로, 학교 등의 다양한 시설로 활용하고 있다 (Fig. 5).

특히 일본은 대심도 지하공간 사용에 관한 특별 조치 법을 2001년부터 시행하고 있다 (MLITT, 2021). 일본은 지하공간을 에너지, 교통, 물류, 폐기물처리 및 처분, 관 광 갱도, 방재 및 홍수조절 등의 도시기반시설과 안전시 설로 활용할 뿐만 아니라 교육, 스포츠, 문화시설, 연구 개발 등의 문화적 용도로도 이용하고 있다 (SI, 2019).

국토가 협소하고 산지와 임야가 $70 \%$ 이상 차지하고 있 는 우리나라의 경우 지하공간은 새롭게 개척해야 할 국 토로 간주하고 지상의 도시기능, 산업시설 등을 적극적 으로 지하로 이전하여 지상과 지하를 유기적으로 결합시 킨 입체적인 국토이용을 통하여 토지이용 효율을 극대화 하고 지하공간을 지상의 개선 및 자연환경의 보호와 에 너지 절약을 위한 시설로서 적극 개발할 필요가 있다 (Shin, 2012).

이처럼 골재채취로 인해 발생되는 지하공간의 활용을 사전에 계획 및 설계하여 단계적으로 골재를 채취한다면, 골재 채취로 인해 발생하는 지하공간은 효과적으로 이용 이 가능하며 이로 인해 다양한 부가가치를 창출할 수 있다.

\section{4. 제도적 보완을 통한 산림골재 생산 활성화 방안}

산림골재를 개발하는데 있어서 골재를 채취할 수 있는 암반의 체적이 얼마나 되느냐는 산림골재의 생산기간과 경제성을 좌우하는 중요한 요소이다. 산지관리법 시행령 36 조의 토석채취허가기준에 의하면, 토석을 굴취, 채취하 려는 지역은 해당 산지의 표고의 100 분의 70 이하로 제한
하고 있다. 이러한 제한은 산지관리법 18 조 (산지전용허 가기준 등)에 따라 주변 지역에 미치는 영향, 집단적 조 림 성공지 및 우량 산림지 편입 정도, 산림의 수질보전 기능, 희귀 야생 동·식물 보전에 미치는 영향 등을 고려 하여 제정되었다. 그러나 이러한 제한 조건은 골재채취 시 7부 능선을 기준으로 급경사 사면을 형성시키게 되고 이는 수직으로 절개된 석산의 모습은 일반인들에게 골재 채취에 관한 부정적인 이미지를 제공한다. 또한 7 부 능 선을 따라 형성된 사면은 암반에 발달한 절리특성이나 암반상태가 불량할 경우 사면 및 벤치 붕괴나 낙석으로 인한 안전사고로 이어질 수 있다. 산림골재 채취장에서 사면붕괴 및 낙석으로 인한 안전사고 사례는 심심치 않 게 언론을 통해 보도되고 있다 (Jeollabuk-do Provincial Daily, 2016; Yonhap News, 2016; YTN, 2013).

또한 채석 허가기간은 산지관리법 시행규칙에 따라 10 년의 범위내로 규정하고 있으나, 행정기관에서는 이를 분 할하여 대개는 3 년이나 5 년으로 허가한 후, 인접 지역에 대해 다시 신규 허가를 받도록 조치하고 있다. 이에 따 라 동일한 석산에서 당해 부지에 대한 채석허가기간이 만료된 경우, 인접 부지에 대하여 채석허가를 받기 위해 서는 주민의 동의와 채석 타당성 평가를 다시 받아야 하 는 애로점이 존재한다 (Choi and Kang, 2001). Korea Construction News (2001)는 산림골재의 난개발이 이루 어지는 근본원인은 골재 채취허가가 단기간에 소규모로 이루어지고, 골재 채취지역이 전국적으로 산재되어 있으 며, 골재업체들이 대부분 영세하기 때문으로 진단하였다.

정부에서는 석재 자원을 체계적으로 개발하고, 채석에 따른 환경 영향을 극소화하며, 개발후 복구 및 복원을 원 활히 수행하기 위해서는 석재 부존량이 풍부한 지역을 대상으로 채석단지를 지정하여 집중 개발할 수 있도록 
산지관리법 29조에 채석단지의 지정 및 해제에 관한 법 률을 2002년에 제정해 시행하고 있다. 채석단지로 지정 되면 단지 전체가 채석허가지역이기 때문에 민원이 감소 하고 장기간의 채석허가와 도로에서 거리제한이 해소되 는 등의 장점이 있으며, 산정형 벤치커트법을 골재채취 에 적용할 수 있어 안전성이 향상되고, 높은 효율과 대 량생산이 가능하다 (Kim et al., 2006). 전국적으로 채석 단지가 활성화된다면 골재수급을 안정시키고 채석지의 사후 이용 및 친환경적 활용이 가능하지만 현재 채석단 지 지정은 저조한 실정이다. 그 이유는 채취업자가 채석 단지를 지정받기 위해서는 승인을 받기까지 오랜 기간이 소요되며 지정신청에 따른 제반 용역비 (채석경제성평가, 환경영향평가) 등의 업무추진비가 과다하게 발생하여 영 세한 사업자에게 큰 부담으로 작용 (Yim et al., 2019)하 고 있고, 채석단지 인근의 지역주민과 환경단체가 향후 발생하게 될 환경문제를 우려해 채석단지 지정을 반대 (Gukje News, 2019; Yonhap News, 2018)하고 있기 때문 이다.

이러한 문제는 관리감독기관, 골재 생산주체, 지역주민 을 포함하는 3자간의 상호 노력을 통해 해결점을 찾아야 한다. 정부와 지자체는 골재수급이 원활할 수 있도록 골 재채취 인허가에 대한 행정적 절차를 간소화하고 안정적 으로 골재채취가 가능하도록 허가면적을 확대하는 등의 지원을 강화하되, 골재채취로 인해 발생할 수 있는 건강, 안전, 환경 문제를 관리 및 감독할 수 있는 시스템 구축 과 더불어 지역주민과 골재생산자간 적극적 중재를 통해 상호 이해의 폭을 넓힐 수 있는 노력을 해야 한다. 또한 안전과 환경에 대한 높은 수준의 사회적 요구에 골재생 산자가 효과적으로 대응할 수 있도록 골재생산시 발생하 는 분진, 소음 및 진동, 슬러지 처리 문제 등을 효과적으 로 해결할 수 있도록 이러한 분야에 대한 연구개발을 적 극적으로 추진해야 한다. 반면에 골재생산자는 효율적인 골재생산, 작업자의 건강과 안전을 고려한 작업환경 마 련, 골재생산으로 인한 환경문제 대응기술을 확보하고, 지역주민의 정당한 요구에 적극적으로 대응하고 투자를 지속함으로서 부정적인 골재산업의 이미지를 개선할 수 있도록 적극적으로 노력해야 한다. 또한 지역주민은 단 순한 보상금이나 지역발전기금을 요구할 것이 아니라 장 기적으로 지역발전과 골재산업에 도움이 될 수 있는 방 안을 함께 고민해 나가야 한다.

\section{5. 결 론}

생산지에서 소비지까지의 운반거리가 골재의 가격에 미치는 영향이 크기 때문에 운반거리가 골재시장의 공간
적 범위를 결정하고 있다. 본 연구에서는 운반거리에 따 라 산림골재 개발을 활성화할 수 있는 방안을 다음과 같 이 제시하였다.

- 골재생산지가 도심에서 원거리에 위치할 경우 운반비 용을 절감시키기 위해 철도와 같은 저렴한 이동수단 을 이용해 도시인근의 골재 저장시설까지 최적화된 경로로 운송하고, 이를 각 중간 판매상이나 수요처에 공급하는 방안을 제시하였다. 이를 위한 적하 및 저 장시설 부지로 기존 폐석산이나 철도유휴부지가 대안 이 될 수 있으며, 골재채취단지와 연계시 안정적 골 재수급에 시너지 효과가 발생할 수 있다.

- 골재생산지가 도심에서 근거리에 위치한 경우에는 지 하에서 골재를 채취하는 방안을 제시하였다. 지하에 서 골재를 채취할 경우 골재 채취지역의 노출이 없으 며, 골재채취로 인한 환경문제를 최소화하면서 인근 골재수요에 대응할 수 있다. 또한 광산개발에 적용되 는 최적 설계기법을 적용하여 효율적인 골재 개발방 안을 수립하고 향후 지하 골재개발로 인해 발생하는 지하공간에 대한 활용계획을 사전에 마련한다면, 지 하 골재채취로 인한 경제성은 향상될 수 있으며 이로 인해 다양한 부가가치가 창출될 수 있다.

- 산림골재의 지속가능한 개발을 위해서는 부정적인 골 재산업의 이미지를 개선과 더불어 최근 높아지고 있 는 환경과 안전에 대한 사회적 요구에 효과적으로 대 응할 수 있어야 한다. 이러한 문제는 정부, 골재 생산 업자, 지역주민을 포함하는 3자간의 상호 노력을 통 해 해결점을 찾아야 한다. 또한 각 주체가 골재개발 로 인한 안전 및 환경 문제에 효과적으로 대응할 수 있도록 이와 관련된 연구개발과 더불어 제도개선이 뒷받침되어야 한다.

\section{사 사}

이 연구는 한국지질자원연구원에서 수행하고 있는 국 토교통부 “2021년 골재자원조사 및 관리사업 (IP2021006)"의 일관으로 수행되었습니다.

\section{References}

Benardos, A.G., Kaliampakos, D.K., Prousiotis, J.G., Mavrikos, A.A. and Skoparantzos, K.A. (2001) Underground aggregate mining in Athens: a promising investment plan. Tunnelling and Underground Space Technology, v.16, p.323-329. doi: 10.1016/ S0886-7798(01)00059-1

Brown, T.J., Coggan, J.S., Evans, D.J., Foster, P.J., Hewitt, J., Kruyswijk, J.B., Millar, D.L., Smith, N. and Steadman, E.J. 
(2010) Underground Mining of Aggregates Main Report. Aggregates Strategic Research Programme Project No. 7

Chan, H.K.K., Millis, S.W., Wallace, M.I. and Hung, K.C. (2019) Hong Kong's Hidden Aggregate Resource: The Potential for Underground Quarrying. HKIE Geotechnical Division Annual Conference 2017, p.10.

Choi, M.S. and Kang, W.S. (2001) The Directions for Improving Administrative Regulations related Quarrying for Crushed Rocks. Construction \& Economy Research Institute of Korea, p.99.

Dammers, M., Barnewold, L., Merchiers, A., Jeschke, P. and Putz, M. (2019) Development of an Underground Haulage System Evaluation Tool for Feasibility Studies. Society for Mining, Metallurgy \& Exploration, v.36, p.487-494. doi: 10.1007/s42461019-0055-9

Eidelman, A., Slutky, D., Bein, A. and Haklai, R. (2007) Underground Mining of Aggregates for the Building and RoadPaving Industry. The Center for Environmental Policy Studies Series, no. 27.

Gukje News (2019.01.09.) Establishment of countermeasures committee against aggregate complex and re-licensing of Buyeo Industrial Development. https://www.gukjenews.com/news/ articleView.html?idxno=1051370, 2021.07.27.

Hong, S.S., Kim, J.Y. and Lee, J.Y. (2015) Trends of Supply and Demand of Aggregate in Korea (I). Jour. Petrol. Soc. Korea, v.24, p.253-272. doi: 10.7854/JPSK.2015.24.3.253

Hong, S.S. and Lee, J.Y. (2020), Analysis of 2019 Domestic Aggregate Production in Korea (I). Econ. Environ. Geol., v.53, p.755-769. doi: 10.9719/EEG.2020.53.6.755

Jeollabuk-do Provincial Daily (2016.04.10) Quarry collapses in Gunsan, hits heavy equipment, 1 Dead. https://www.domin. co.kr/news/articleView.html?idxno=1105189, 2021.07.27.

Kim, Y.H., Choi, M.S., Oh, G.G., Moon, S.B. and Jo, H.J. (2006) Measures to improve quarry permits and restoration systems, Korea Forest Service, p.185.

Korea Aggregates Association (KAA) (2021.07.12.) http:// www.aak.or.kr/action.do?a=GOAMain\& $\mathrm{c}=1001,2021.07 .27$.

Korea Construction News (2001.12.18) About the importance of aggregate. http://www.conslove.co.kr/news/articleView.html?idxno $=741,2021.07 .27$.

Korea Institute of Geoscience \& Mineral Resources (KIGAM) (2019) Development of mineral potential targeting and efficient mining technologies based on 3D geological modeling platform. KR-2019-Basic-30-2019.
Korea Institute of Geoscience \& Mineral Resources (KIGAM) (2020) Planning for comprehensive management of industrial stones and natural aggregate resources. JP2020-001-2020(1).

Korea National Railway (KNR) (2021.07.13.) https://www.kr.or.kr/ main.do, 2021.07.27.

Korea National Railway (KNR) (2021.07.18.) http://www.kr.or.kr/ sub/info.do?m=04050401\&s=krhome, 2021.08.18.

Korea National Railway (KNR) (2002) management plan for railway idle site in 2020

Ministry of Land, Infrastructure and Transport (MLIT) (2018) Annual aggregate statistics (1993-2023). www.agris.go.kr, 2021. 07.27.

Ministry of Land, Infrastructure and Transport (MLIT) (2018) The 6th Basic Plan for Aggregate Supply and Demand (2019-2023). https:/www.agris.go.kr/agris2/board/gosiList.do, 2021.07.27.

Ministry of Land, Infrastructure, Transport and Tourism (MLITT) https://www.mlit.go.jp/toshi/daisindo/index.html, 2021.07.27.

Shin, H.S. (2012) Current status and prospects of domestic and international underground space development. Technology Development Ssangyong, p.4-11.

Stocks, J. (1979) The Production of Aggregate by Underground Mining Methods-Development of a Simulation Technique for Prefeasibility Analysis. Minerals and the Environment, v.1, p.148-160. doi: 10.1007/BF01999702

The Seoul Institute (SI) (2019) Constructions of energy, logistics, disaster prevention facilities, etc. by taking advantage of the advantages of underground space (except Tokyo, Japan). World Urban Trends, v.446, https://www.si.re.kr/node/60967, 2021.07.27.

Won, H.Y. (2004) Supply and Demand Prospects of Aggregate and Future Measures. Construction Economy, v.39, p.47-52.

Yim, S.H., Lee, D.G. and Kim, H.Y. (2019) A Study on the Efficient Restoration and Post-Utilization of Earth and Stone Extraction Sites. Jeonbuk Institute, p.136.

Yonhap News (2016.03.30.) Quarry collapses in Gumsan...50-yearold man dies. https://www.yna.co.kr/view/AKR20160330158651063, 2021.07.27.

Yonhap News (2018.02.05) Negative for permission of large-scale quarrying complex in Yeosu...Strong opposition from residents. https://www.yna.co.kr/view/AKR20180205100200054, 2021.07.27.

YTN (2013.09.03) Ground collapse during quarry work...1 person died. https://www.ytn.co.kr/_ln/0115_201309030001349409, 2021. 07.27 . 